\title{
Impaired tyrosine-kinase activity of muscle insulin receptors from hypomagnesaemic rats
}

\author{
A. Suárez, N. Pulido, A. Casla, B. Casanova, F. J. Arrieta, A. Rovira \\ Department of Endocrinology, Fundación Jiménez Díaz, Universidad Autónoma de Madrid, Madrid, Spain
}

Summary The effect of magnesium deficiency on glucose disposal, glucose-stimulated insulin secretion and insulin action on skeletal muscle was investigated in rats which were fed a low magnesium-containing diet for 4 days. Control rats were fed a standard diet. Compared to the control rats, the rats fed with low magnesium diet presented: 1) lower serum magnesium levels $(0.45 \pm 0.02$ vs $0.78 \pm 0.01 \mathrm{mmol} / \mathrm{l}$, $p<0.001), 2)$ higher basal serum glucose $(6.8 \pm 0.2 \mathrm{vs}$ $5.5 \pm 0.2 \mathrm{mmol} / 1, p<0.05)$ and similar basal serum insulin, 3) $40 \%$ reduction $(p<0.001)$ in the glucose disappearance rate after its i.v. administration, and 4) $45 \%$ reduction $(p<0.05)$ in the glucose-stimulated insulin secretion. The insulin action upon the glucose uptake by skeletal muscle was determined by means of hindquarter perfusions. Compared with control rats, magnesium-deficient rats presented: 1) normal basal glucose uptake, 2) lower stimulatory effect on the glucose uptake by insulin at the concentrations of $5 \times 10^{-10} \mathrm{~mol} / 1 \quad(3.0 \pm 0.9$ vs $5.4 \pm 0.6$, $p<0.05)$ and $5 \times 10^{-9} \mathrm{~mol} / \mathrm{l}(6.3 \pm 0.5$ vs $8.0 \pm 0.5$, $p<0.05), 3$ ) normal glucose uptake at a maximal insulin concentration of $1 \times 10^{-7} \mathrm{~mol} / 1$, and 4) $50 \%$ reduction in the insulin sensitivity $\left(\mathrm{ED}_{50}: 1.3 \pm 0.3 \mathrm{vs}\right.$
$0.55 \pm 0.1 \mathrm{~mol} / 1, p<0.05)$. In partially purified insulin receptors prepared from gastrocnemius muscle, ${ }^{125} \mathrm{I}$ insulin binding was similar in both groups of rats. However, the autophosphorylation of the $\beta$-subunit of the insulin receptor was significantly reduced by $50 \%$ in magnesium-deficient rats and the tyrosine kinase activity of insulin receptors toward the exogenous substrate Poly Glu4: Tyr 1 was also reduced $(p<0.05)$ by hypomagnesaemia. The abundance of the insulin-sensitive glucose transporter protein (muscle/fat GLUT4), measured by Western blot analysis using polyclonal antisera, was similar in muscles of control and hypomagnesaemic rats. These findings indicate that hypomagnesaemia has a deleterious effect on glucose metabolism due to an impairment of both insulin secretion and action. The insulin resistance observed in skeletal muscle of magnesium-deficient rats may be attributed, at least in part, to a defective tyrosine kinase activity of insulin receptors. [Diabetologia (1995) 38: 1262-1270]

Key words Magnesium, insulin receptors, tyrosine kinase, skeletal muscle, insulin secretion, glucose disposal, GLUT 4.
Received: 25 January 1994 and in revised form: 8 May 1995

Corresponding author: Dr. A. Rovira, Department of Endocrinology, Fundación Jiménez Díaz, Avda. Reyes Católicos, 2, E28040 Madrid, Spain

Abbreviations: WGA, Wheat germ agglutinin agarose; Hepes, $\mathrm{N}$-2-hydroxyethylpiperazine- $\mathrm{N}^{\prime}$-2-ethane sulphonic acid; PMSF, phenylmethylsulphonyl fluoride; TBS, Tris buffered saline; IVGTT, intravenous glucose tolerance test.
Among the different hormones, insulin is an important modulator of the cellular content of magnesium $[1,2]$, the most abundant intracellular divalent cation. Insulin-resistant patients have an impaired insulin-mediated erythrocyte magnesium accumulation [3-5] which correlates with a decrease in insulin sensitivity $[3,4]$. On the other hand, magnesium is a cofactor of many enzymes involved in glucose metabolism, especially those using high energy phosphate bonds [6]. In vitro studies have shown that this cation has an important role in insulin action $[1,7]$. A relation- 
ship between hypomagnesaemia and insulin resistance has been reported among diabetic patients [8, 9], and furthermore, chronic administration of magnesium has been found to improve the insulin sensitivity in non-insulin-dependent diabetic subjects [10] and in patients with severe hypomagnesaemia [11].

Insulin binding to specific cell surface receptors is the initial event in insulin action on target tissues. Insulin receptors are heteroligomeric glycoproteins consisting of two $\alpha$-subunits $(130-135 \mathrm{kDa})$, which bind insulin, and two $\beta$-subunits $(90-95 \mathrm{kDa})$, which possess an intrinsic tyrosine kinase activity. It has been postulated that the activation of the protein kinase of the insulin receptor is an important step in transmembrane signalling for insulin action. There are several examples where alterations in receptor kinase activity could explain an impairment of the insulin action [12-16].

In this study, our aim was to investigate the effect of hypomagnesaemia on the insulin action in skeletal muscle, the major site of peripheral insulin-stimulated glucose disposal. The overall glucose disposal and the glucose-stimulated insulin secretion were also studied.

\section{Materials and methods}

Materials. Porcine monocomponent insulin (Novo Research Institute, Copenhagen, Denmark) was used for insulin studies and iodination by the chloramine $T$ method [17] at a specific activity of $185 \mu \mathrm{Ci} / \mu \mathrm{g}$. $\left[\gamma^{32} \mathrm{P}\right]-\mathrm{ATP}(4,000 \mathrm{Ci} / \mathrm{mmol})$ was purchased from ICN Biomedicals, ICN (Costa Mesa, Calif., USA). Wheat germ-agglutinin agarose (WGA) was prepared from lectin and cyanogen bromide-activated Sepharose $4 \mathrm{~B}$ (Pharmacia LKB, Uppsala, Sweden). Bovine serum albumin radioimmunoassay-grade Fraction V, N-2-hydroxyethylpiperazine-N'-2-ethane sulphonic acid (Hepes), Poly Glu4:Tyrl (4:1), phenylmethylsulphonyl fluoride (PMSF), leupeptin, pepstatin, bacitracin, vanadate, sodium fluoride, 2-acetamido-2-deoxy-D-glucose ( $\mathrm{N}$-acetyl-D-glucosamine) and pyrophosphate were obtained from Sigma (St. Louis, Mo., USA). Aprotinin was from Boehringer Mannheim (Mannheim, Germay). Reagents for polyacrylamide gel electrophoresis and Triton X-100 were obtained from Bio-Rad Laboratories (Richmond, Calif., USA). Anti-insulin receptor antibody (AB-3) was from Oncogene Science, INC (Uniondale, N.Y., USA). All other chemicals were of analytical grade. The magnesium content in serum and in dry skeletal muscle (gastrocnemius) and serum calcium were measured by an automated atomic absorption procedure, using a Perkin-Elmer 305B spectrophotometer (Perkin-Elmer, Norwalk, Connecticut, USA). Protein determination was performed by the Bradford dye method (Bio-Rad Laboratories Richmond $\mathrm{GmbH}$, Munich, Germany). Serum insulin levels were measured by radioimmunoassay [18] using rat insulin standard (Novo Research Institute). Serum glucose levels were determined by the glucose-oxidase method using a Beckman 2 Glucose Analyzer (Beckman Instruments S. A., Madrid, Spain).

Experimental animals. Experiments were performed on male albino Wistar rats weighing $180-200 \mathrm{~g}$, bred in our centre. Rats were fed a diet containing low magnesium $(3.8 \mathrm{mg} / \%)$ for 4 days; control rats were fed a standard $\mathrm{Mg}^{+2}$-containing $\operatorname{diet}(85.8 \mathrm{mg} / \%)$ for 4 days.

Intravenous glucose tolerance test. After a 12-h fasting period rats were anaesthetized with an i.p. injection of sodium pentothal $(75 \mathrm{mg} / \mathrm{kg}$ body weight). An intravenous glucose tolerance test (IVGTT) was performed as described by Varnum et al. [19], with minor modifications. After tracheotomy, a catheter was placed into the right common carotid artery and a basal blood sample was taken. Glucose $(0.5 \mathrm{~g} / \mathrm{kg}$ body weight $)$ was then quickly injected and the catheter flushed with $0.9 \%$ $\mathrm{NaCl}$ containing heparin. Blood samples were drawn at 4,8 , $12,16,20$, and $30 \mathrm{~min}$ after injection. Serum was separated from blood cells by centrifugation and stored at $-20^{\circ} \mathrm{C}$ until the glucose and the insulin contents were assayed. The glucose disappearance rate was expressed as the $\mathrm{K}$ index, calculated from the formula $K=\left(0.6931 / t_{1 / 2}\right) \times 100$, where $t_{1 / 2}$ is the time in minutes required to halve the glucose concentration.

Hindquarter perfusion. Male Wistar rats were fasted for $16 \mathrm{~h}$ before perfusion. The muscle perfusion system we used was based on the method described by Ruderman et al. [20] and modified by Dohm et al. [21]. After anaesthesia with sodium pentothal $(75 \mathrm{mg} / \mathrm{kg}$ body weight, i.p.), a midline abdominal incision was made. The lower colon was ligated and excised. Internal spermatic, iliolumbar, left renal, superficial epigastric and hypogastric vessels were ligated. Loose ligatures were placed around the aorta proximal to the left renal vein and around the vena cava distal to the juction with the right renal vein. These ligatures were then quickly tightened and the animal was transected just before the last secured ligatures. The hemicorpus was transferred to the perfusion chamber (maintained at $37^{\circ} \mathrm{C}$ ) and cannulae were quickly inserted into the aorta and vena cava. Flow of the perfusion medium was started as soon as possible and the interruption of oxygenation of the hemicorpus was less than 2 min from the ligation of the aorta until flow was reestablished. The hemicorpus was perfused with Krebs-Henseleit solution, $\mathrm{pH} 7.4$, containing $5.5 \mathrm{mmol} / \mathrm{l}$ glucose, $0.15 \mathrm{mmol} / \mathrm{l}$ pyruvate, $4 \%$ bovine serum albumin (Fraction V, Sigma) and $30 \%$ washed bovine erythrocytes. The flow rate was maintained at $12 \mathrm{ml} / \mathrm{min}$. Pressure was measured by a mercury manometer connected by a side arm to the arterial tubing. After a $50-\mathrm{ml}$ washout period, the perfusate $(100 \mathrm{ml})$ was recirculated for the duration of the perfusion. The aortic pressure remained at $80-100 \mathrm{~mm} \mathrm{Hg}$ throughout this period. The perfusion medium was oxygenated in a Silastic tube oxygenator ( $7 \mathrm{~m}$ long, $1 \mathrm{~mm}$ in diameter and $0.2 \mathrm{~mm}$ wall thickness) suspended in another tube flushed with oxygen. The hindquarters were perfused for a total of $100 \mathrm{~min}: 25 \mathrm{~min}$ without insulin, $25 \mathrm{~min}$ with $5 \times 10^{-10} \mathrm{~mol} / 1$ insulin, $25 \mathrm{~min}$ with $5 \times 10^{-9} \mathrm{~mol} / 1$ insulin and $25 \mathrm{~min}$ with $10^{-7} \mathrm{~mol} / 1$ insulin. When $5 \times 10^{-9}$ and $10^{-7} \mathrm{~mol} / 1$ insulin was added, glucose was also added to the perfusion medium to reach the initial concentration of $5.5 \mathrm{mmol} / \mathrm{l}$. Samples were taken every $5 \mathrm{~min}$ for glucose assay and calculation of glucose uptake.

Insulin receptor purification. Rats were killed by cervical dislocation, and the gastrocnemius muscles were quickly removed, frozen under liquid nitrogen, and stored at $-70^{\circ}$ until receptor purification was performed. Frozen muscles were powdered in liquid nitrogen, and homogenized in $50 \mathrm{mmol} / \mathrm{l}$ Hepes buffer, $\mathrm{pH} 7.4$, containing $1 \%$ Triton $\mathrm{X}-100,50 \mathrm{mmol} / 1 \mathrm{NaCl}$, $2 \mu \mathrm{mol} / 1$ leupeptin, $2 \mu \mathrm{mol} / 1$ pepstatin, $1 \mathrm{mmol} / 1 \mathrm{PMSF}, 1 \mathrm{mg} /$ $\mathrm{ml}$ bacitracin, $1 \mathrm{mmol} / 1$ vanadate, $1,000 \mathrm{U} / 1$ aprotinin, $10 \mathrm{mmol} / 1$ pyrophosphate, $8 \mathrm{mmol} / \mathrm{l} \mathrm{EDTA}$ and $100 \mathrm{mmol} / \mathrm{l}$ $\mathrm{NaF}$. The homogenate was centrifuged at $10,000 \times \mathrm{g}$ for $20 \mathrm{~min}$ at $4^{\circ} \mathrm{C}$ and the supernatant containing cellular mem- 
branes was solubilized by stirring at $4^{\circ} \mathrm{C}$ for $60 \mathrm{~min}$. The insoluble material was removed by centrifugation for $90 \mathrm{~min}$ at $100,000 \times g$ at $4^{\circ} \mathrm{C}$. The soluble extracts were used for preparing insulin receptors and for measuring the content of the glucose transporter GLUT 4. Partially purified insulin receptors were prepared following the method of Hedo et al. [22]. In essence, the soluble extract was incubated overnight at $4^{\circ} \mathrm{C}$ with $4 \mathrm{ml}$ of WGA, and after extensive washing with $50 \mathrm{mmol} / 1 \mathrm{He}-$ pes buffer ( $\mathrm{pH} 7.4$ ) containing $150 \mathrm{mmol} / \mathrm{l} \mathrm{NaCl}, 0.1 \mathrm{mmol} / 1$ PMSF and $0.1 \%$ Triton X-100 (WGA buffer), the bound glycoproteins including the insulin receptor were eluted using the WGA buffer with $0.3 \mathrm{~mol} / 1 \mathrm{~N}$-acetyl-D-glucosamine. These partially purified insulin receptor preparations were used to measure ${ }^{125} \mathrm{I}$-insulin binding and tyrosine-specific protein kinase activity. The amount of protein used in these assays was $15 \mu \mathrm{g}$ as estimated by the Bradford reaction [23].

Insulin binding to purified insulin receptors. Partially purified solubilized receptors were incubated in duplicate, in a final volume of $250 \mu \mathrm{l}$ of WGA buffer, in the presence of $10^{-10} \mathrm{~mol} / \mathrm{l}$ ${ }^{125}$ I-insulin and in the absence or the presence of increasing concentrations of unlabelled insulin $\left(10^{-10}-10^{-6} \mathrm{~mol} / \mathrm{l}\right)$ for $16 \mathrm{~h}$ at $4{ }^{\circ} \mathrm{C}$. The ${ }^{125} \mathrm{I}$-insulin bound to the receptor was precipitated by the addition of $500 \mu \mathrm{l}$ of $0.1 \%$ human $\gamma$-globulin and $500 \mu \mathrm{l}$ of $25 \%$ (w/w) polyethyleneglycol and collected by centrifugation in a Beckman J-6B centrifuge $(4,000 \times g$ for $45 \mathrm{~min}$ at $4^{\circ} \mathrm{C}$ ). The pellet was then washed with $1 \mathrm{ml}$ of $12.5 \%$ polyethyleneglycol and separated again by centrifugation. The resulting pellet was counted for gamma-radioactivity. Specific ${ }^{125} \mathrm{I}$-insulin binding was determined for each insulin concentration after subtracting the non-specific value obtained in the presence of $10^{-6} \mathrm{~mol} / 1$ unlabelled insulin. The degradation of ${ }^{125}$ I-insulin as determined by trichloroacetic acid precipitation was less than $10 \%$ under the assay conditions. The binding capacity was calculated by Scatchard analysis [24].

Tyrosine kinase activity: phosphorylation of an exogenous substrate. Insulin receptors were incubated in triplicate in the absence and presence of insulin $\left(10^{-7} \mathrm{~mol} / \mathrm{l}\right)$ at $4^{\circ} \mathrm{C}$ for $16 \mathrm{~h}$. The tyrosine-specific protein kinase activity was then determined at room temperature using the method of Grunberger et al. [25], with minor modifications. In brief, $\left[\gamma^{32} \mathrm{P}\right]-\mathrm{ATP}(2.5 \mu \mathrm{Ci}$, $100 \mu \mathrm{mol} / \mathrm{l}$ ) was added in the presence of $2.5 \mathrm{mg} / \mathrm{ml}$ of the exogenous substrate Poly Glu4:Tyr1, $10 \mathrm{mmol} / 1 \mathrm{MgCl}_{2}$, and $0.5 \mathrm{mmol} / 1 \mathrm{MnCl}_{2}$, in $50 \mathrm{mmol} / 1$ Hepes buffer, $\mathrm{pH}$ 7.4. The reaction was stopped after $30 \mathrm{~min}$ with $10 \%$ trichloroacetic acid containing $10 \mathrm{mmol} / \mathrm{l}$ pyrophosphate. Reagent blanks were subtracted. Results are expressed as pmol of $\left[{ }^{32} \mathrm{P}\right]$ incorporated into Poly Glu4:Tyr1 per $\mu \mathrm{g}$ of the receptor preparation.

Insulin receptor autophosphorylation. Insulin receptors were incubated in the absence and the presence of insulin $\left(10^{-7}\right.$ $\mathrm{mol} / \mathrm{l})$ at $4^{\circ} \mathrm{C}$ for $16 \mathrm{~h}$; then $\left[\gamma^{32} \mathrm{P}\right]-\mathrm{ATP}(40 \mu \mathrm{Ci}, 50 \mu \mathrm{mol} / \mathrm{l})$ was added in the presence of $5 \mathrm{mmol} / 1 \mathrm{MgCl}_{2}$ and $10 \mathrm{mmol} / \mathrm{l}$ $\mathrm{MnCl}_{2}$ in $50 \mathrm{mmol} / \mathrm{l}$ Hepes buffer, $\mathrm{pH}$ 7.4. The reaction was terminated after $60 \mathrm{~min}$ with an equal volume of $50 \mathrm{mmol} / 1$ Hepes buffer containing $10 \mathrm{mmol} / 1 \mathrm{EDTA}, 100 \mathrm{mmol} / \mathrm{l} \mathrm{NaF}$, $20 \mathrm{mmol} / 1 \mathrm{pyrophosphate,} \mathrm{and} 4 \mathrm{mmol} / \mathrm{l}$ ATP. The mixture was incubated for $16 \mathrm{~h}$ at $4^{\circ} \mathrm{C}$ with monoclonal insulin receptor antibody (AB-3) and protein A-agarose plus goat anti-mouse IgG. The immunoprecipitates were then centrifuged at $2,500 \times g$ for $15 \mathrm{~min}$ at $4^{\circ} \mathrm{C}$ and washed first with WGA buffer, then with WGA buffer containing $0.5 \mathrm{mmol} / 1 \mathrm{NaCl}$ and fi-

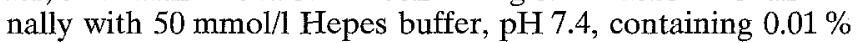
SDS. Pellets were suspended in Laemmli buffer with $3 \%$ dithiothreitol, boiled for $5 \mathrm{~min}$, and subjected to SDS polyacrylamide $(7.5 \%)$ slab gel electrophoresis [26]. The $\beta$-subunit of the insulin receptor was localized in the autoradiography and measured by densitometry.

Cross-linkage of solubilized insulin receptors with ${ }^{125} I$-insulin. After optimal ${ }^{125} \mathrm{I}$-insulin binding in the absence and presence of unlabelled insulin $\left(10^{-8}\right.$ and $\left.10^{-7} \mathrm{~mol} / \mathrm{l}\right)$, equal amounts of the ${ }^{125} \mathrm{I}$-insulin receptor complex were covalently cross-linked with $1 \mathrm{mmol} / \mathrm{l}$ disuccinimidyl suberate for $15 \mathrm{~min}$ at $4^{\circ} \mathrm{C}$ using the method of Pilch and Czech [27]. The samples were suspended in Laemmli buffer with $3 \%$ dithiothreitol and boiled for $5 \mathrm{~min}$. PAGE was performed according to the method of Laemmli [26] in a $7.5 \%$ gel. The gels were fixed, dried, and autoradiographed for $24 \mathrm{~h}$ at $-70^{\circ} \mathrm{C}$ with Kodak X-Omat film using lighting plus screen. The electrophoretic migration of the cross-linked $\alpha$-subunit of the insulin receptor was localized in the autoradiography.

Analysis of the glucose transporter protein GLUT 4. The insulin-sensitive glucose transporter protein (muscle/fat GLUT 4) was measured by Western blot analysis in the solubilized material obtained from homogenates of gastrocnemius muscles. An aliquot of the soluble extract ( $50 \mu \mathrm{g}$ protein) was mixed with $50 \mu \mathrm{l}$ Laemmli sample buffer containing $5 \%$ dithiothreitol, brought to a total volume of $100 \mu \mathrm{l}$ with $25 \mathrm{mmol} / \mathrm{l}$ Tris, $190 \mathrm{mmol} / 1$ glycine, $\mathrm{pH} 8.4$ containing $0.1 \%$ SDS, and left overnight at $4^{\circ} \mathrm{C}$. Proteins were separated by SDS polyacrylamide gel electrophoresis on $10 \%$ resolving gel using Laemmli's method [26], and transferred to Immobilon membrane by electrotransfer. The membrane was blocked for $2 \mathrm{~h}$ with $5 \%$ Carnation Low-fat Instant Milk in Tris buffered saline (TBS), followed by incubation with $10 \mu \mathrm{g}$ of a polyclonal antisera raised in rabbits specific for a 12-amino acid peptide based on the deduced carboxyl-terminal sequence of the GLUT 4 [28]. After a 16-h incubation at $4^{\circ} \mathrm{C}$ the membrane was washed alternatively in TBS- $0.05 \%$ Tween and probed for $3 \mathrm{~h}$ with ${ }^{125} \mathrm{I}$-goat anti-rabbit IgG. Autoradiography was carried out for $48 \mathrm{~h}$ at $-70^{\circ} \mathrm{C}$.

\section{Statistical analysis}

Results are given as mean \pm SEM. Student's $t$-test for unpaired data was used to evaluate the statistical significance of differences between hypomagnesaemic and control groups. Correlation coefficients were calculated by linear regression analysis. Areas under the curves were determined using the trapezoidal rule.

\section{Results}

Animal characteristics. After 4 days on the diet, the mean serum magnesium level was significantly lower $(p<0.001)$ in the group of hypomagnesaemic rats $(0.45 \pm 0.02 \mathrm{mmol} / 1$, range: $0.25-0.64)$ in comparison with that in the control group $(0.78 \pm 0.01 \mathrm{mmol} / \mathrm{l}$, range: $0.66-0.88$; Table 1$)$. Certain animals presented the classic syndrome of magnesium deficiency, characterized by hyperaemia of the skin and hyperexcitability. The initial and final weights in both groups of rats were similar. Serum calcium levels were slightly increased in hypomagnesaemic rats $(2.62 \pm 0.03$ vs $2.45 \pm 0.05 \mathrm{mmol} / 1, p=\mathrm{NS}$ ). The magnesium content 
Table 1. Characteristics of the animals studied

\begin{tabular}{lll}
\hline & Control & Hypomagnesaemic \\
\hline $\begin{array}{l}\text { Serum magnesium } \\
(\mathrm{mmol} / \mathrm{l})\end{array}$ & $0.78 \pm 0.01(32)$ & $0.45 \pm 0.02(36)^{\mathrm{b}}$ \\
$\begin{array}{l}\text { IVGTT } \\
\text { Basal glucose }(\mathrm{mmol} / \mathrm{l})\end{array}$ & $5.50 \pm 0.16(8)$ & $6.80 \pm 0.23(12)^{\mathrm{a}}$ \\
Basal insulin (nmol/l) & $0.45 \pm 0.03(8)$ & $0.52 \pm 0.03(12)$ \\
K index \%/min & $2.80 \pm 0.20(8)$ & $1.70 \pm 0.10(12)^{\mathrm{b}}$ \\
$\begin{array}{l}\text { Area of insulin } \\
\text { nmol } \cdot \mathrm{l}^{-1} \cdot \min ^{-1}\end{array}$ & $59.0 \pm 11.0(8)$ & $32.3 \pm 6.20(12)^{\mathrm{a}}$ \\
\hline
\end{tabular}

Results are mean \pm SEM. ${ }^{\mathrm{a}} p<0.05 ;{ }^{\mathrm{b}} p<0.001$ vs control group; all other comparisons NS. Number of individual observations shown in parentheses
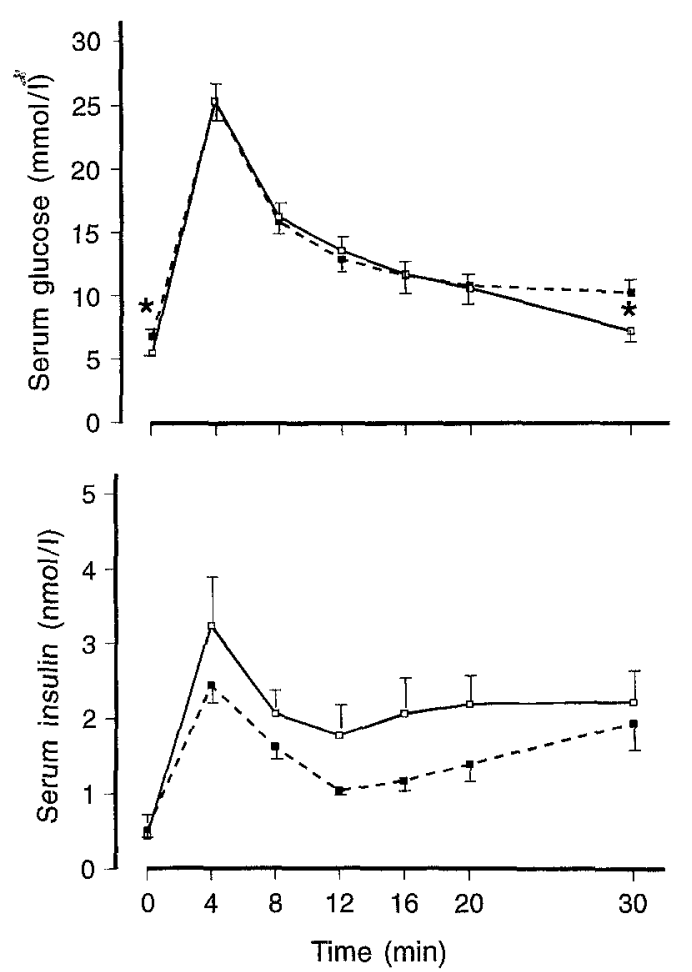

Fig. 1. Serum levels of glucose and insulin during IVGTT in control ( $\square-\square, n=8$ ) and hypomagnesaemic ( $\square-\cdots, n=12$ ) rats. Mean $\pm \mathrm{SEM} ; * p<0.05$ between groups

in gastrocnemius muscles from hypomagnesaemic rats was moderately lower than in control rats $(437 \pm 90$ vs $486 \pm 137 \mu \mathrm{g} / \mathrm{g}$ dry tissue, $p=\mathrm{NS})$.

Intravenous glucose tolerance test (IVGTT). In Table 1 and Figure 1 the results of the IVGTT are shown. Hypomagnesaemic rats presented a significantly $(p<0.05)$ higher mean basal serum glucose level. After the glucose load, both groups of rats had similar blood glucose values up to $20 \mathrm{~min}$, and thereafter magnesium-deficient rats had a higher $(p<0.05)$ glycaemia at $30 \mathrm{~min}$. The glucose disappearance rate, calculated as the $\mathrm{K}$ index, was reduced by $40 \% \quad(1.7 \pm 0.1$ vs $2.8 \pm 0.2 \% / \mathrm{min}$, $p<0.001)$ in hypomagnesaemic rats. A significant correlation between serum magnesium levels and the $\mathrm{K}$ index was found in the total group of rats $(r=0.74, p<0.001)$. The mean basal serum insulin level was not different between the two groups of rats. After the glucose load, serum insulin levels tended to be lower in the hypomagnesaemic compared with the control rats. The mean post-glucose incremental area of insulin up to $30 \mathrm{~min}$ was significantly lower in the hypomagnesaemic rats compared to the control rats $\left(32.3 \pm 6.2\right.$ vs $59.0 \pm 11.0 \mathrm{nmol} \cdot \mathrm{l}^{-1} \cdot \mathrm{min}$, respectively, $p<0.05$ ), and correlated with serum magnesium levels in the total group of rats $(r=0.46$, $p<0.05)$.

Hindquarter perfusion. The data on the glucose uptake by the perfused hindquarters from the two groups of rats are shown in Table 2. No significant differences in the glucose uptake by the hindquarters were observed between the two groups of rats, although hypomagnesaemic rats had a tendency to have a higher mean basal value and a lower glucose disappearance rate in the presence of all the insulin concentrations assayed. The increments above the basal value of the glucose uptake produced by insulin $5 \times 10^{-10} \mathrm{~mol} / 1$ and $5 \times 10^{-9} \mathrm{~mol} / 1$ were significantly lower $(p<0.05)$ in hypomagnesaemic rats compared with control rats, whereas that which was induced by a maximal insulin concentration of $1 \times 10^{-7} \mathrm{~mol} / 1$ was similar in the two groups of rats (Fig.2). Compared with control rats, magnesium-deficient rats presented a shift to the right in the insulin response curve, with a significant decrease in the insulin sensitivity as determined by a higher insulin concentration for achieving the half-maximal glucose uptake $\left(\mathrm{ED}_{50}: 0.55 \pm 0.1\right.$ vs $1.3 \pm 0.3 \mathrm{nmol} / 1$, $p<0.05)$. A negative correlation between the $\mathrm{ED}_{50}$ and serum magnesium levels was found in the total group of rats $(r=-0.81, p<0.005)$.

Insulin binding to purified insulin receptors. The maximal specific ${ }^{125} \mathrm{I}$-insulin binding to partially purified insulin receptors obtained from skeletal muscle and its displacement by increasing concentrations of unlabelled insulin was similar in hypomagnesaemic and control rats (Fig.3). The binding affinity calculated as the concentration of unlabelled insulin which was needed to produce a $50 \%$ decrease in insulin binding $\left(\mathrm{ID}_{50}\right)$ was similar in both groups of rats (hypomagnesaemic rats $1.9 \pm 0.10$ vs control rats $\left.1.9 \pm 0.10 \times 10^{-9} \mathrm{~mol} / 1\right)$. The Scatchard analysis of the binding data showed that the binding capacity of insulin receptors of high and low affinity were unchanged in magnesium-deficient rats.

Insulin receptor tyrosine kinase activity. The tyrosine kinase activity of partially purified insulin receptors from skeletal muscle, determined as the ability to phosphorylate the exogenous substrate Poly 
Table 2. Glucose uptake by perfused hindquarters from control and hypomagnesaemic rats

\begin{tabular}{llllll}
\hline & \multicolumn{3}{l}{ Insulin concentrations $(\mathrm{mol} / \mathrm{l})$} & & \\
\cline { 2 - 6 } & 0 & $5 \times 10^{-10}$ & $5 \times 10^{-9}$ & $10^{-7}$ & $\mathrm{ED}_{50}\left(\mathrm{nmol}^{-1}\right)$ \\
\hline Control rats $(n=10)\left(\mu \mathrm{mol} \cdot \mathrm{g}^{-1} \cdot \mathrm{h}^{-1}\right)$ & $3.9 \pm 0.3$ & $9.3 \pm 0.6$ & $11.5 \pm 0.4$ & $14.1 \pm 0.9$ & $0.55 \pm 0.1$ \\
Hypo-MG $\mathrm{MG}^{+2} \operatorname{rats}(n=7)\left(\mu \mathrm{mol} \cdot \mathrm{g}^{-1} \cdot \mathrm{h}^{-1}\right)$ & $4.6 \pm 0.5$ & $7.7 \pm 0.9$ & $10.9 \pm 0.4$ & $13.4 \pm 0.6$ & $1.30 \pm 0.3^{\mathrm{a}}$ \\
\hline
\end{tabular}

Results are mean $\pm \mathrm{SEM} ;{ }^{\mathrm{a}} p<0.05$ between groups

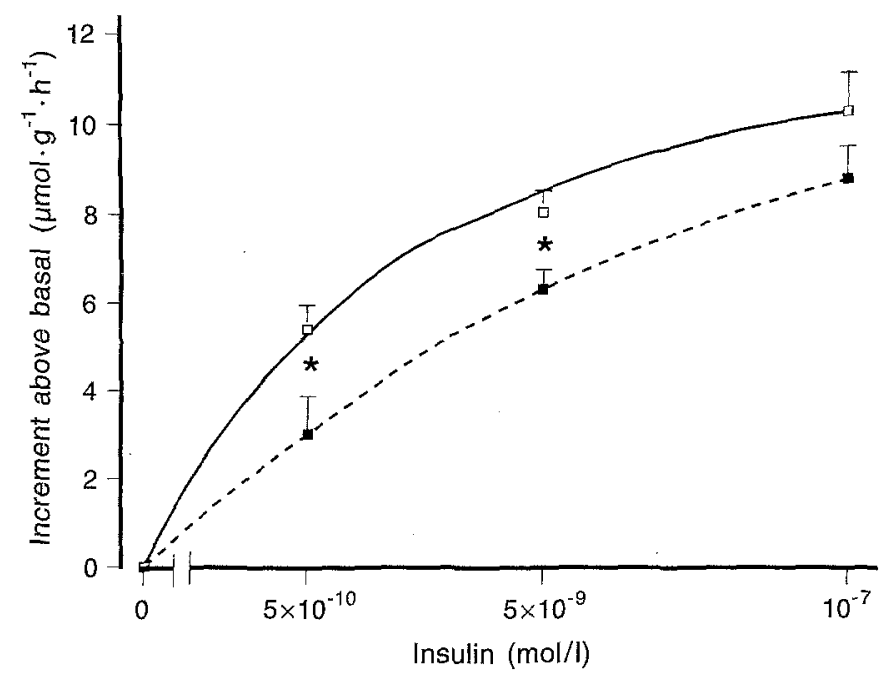

Fig. 2. Increment of the glucose uptake over the basal value by

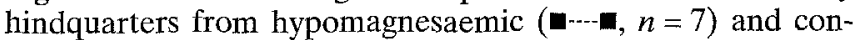
trol ( $\square \square, n=10)$ rats. Mean \pm SEM; * $p 0.05$ between groups

Glu4:Tyr1, was found to be significantly reduced in magnesium-deficient rats (Fig. 4). The kinase activity of insulin receptors from hypomagnesaemic rats was reduced by $30 \%$ in the basal state $(3.7 \pm 0.2$ vs $5.3 \pm 0.4 \mathrm{pmol}$ for ${ }^{32} \mathrm{P}$ incorporated into Poly Glu4:Tyr $1 / \mu \mathrm{g}$ of receptor protein, $p<0.01$ ) and by $17 \%$ at $10^{-7} \mathrm{~mol} / \mathrm{l}$ insulin $(22.1 \pm 0.9$ vs $26.5 \pm 1.6 \mathrm{pmol}^{32} \mathrm{P} / \mu \mathrm{g}$ of protein, $p<0.05$ ). The increment above the basal value induced by insulin of the receptor kinase activity was also reduced in hypomagnesaemic rats compared with the control group $\left(18.4 \pm 0.8\right.$ vs $21.2 \pm 1.5 \mathrm{pmol}^{32} \mathrm{P} / \mu \mathrm{g}$ of receptor protein, respectively, $p<0.05$ ). The autophosphorylation of the $\beta$-subunit of insulin receptors from skeletal muscle was greatly impaired in hypomagnesaemic rats (Fig.4). Insulin receptors from magnesium-deficient rats had a $50 \%$ reduction in their autophosphorylation at basal $(0.49 \pm 0.15$ vs $1.03 \pm 0.11$ arbitrary units $/ \mathrm{fmol}$ insulin bound, $p<0.05$ ) and at $10^{-7} \mathrm{~mol} / \mathrm{l}$ insulin $(1.28 \pm 0.31$ vs $2.70 \pm 0.11 \mathrm{U} / \mathrm{fmol}$ insulin bound, $p<0.05)$. The effect of insulin on the autophosphorylation of the $\beta$-subunit of insulin receptors was therefore also reduced by $50 \%$ in hypomagnesaemic rats $(0.79 \pm 0.15$ vs $1.67 \pm 0.12 \mathrm{U} / \mathrm{fmol}$ insulin bound, $p<0.01)$. The electrophoretic mobility of the $\beta$-subunit of insulin receptors was similar in hypomagnesaemic and control rats, with a molecular mass of approximately $95 \mathrm{kDa}$.
Cross-linkage of solubilized insulin receptors with ${ }^{125}$ I-insulin. To further characterise the insulin receptor, we determined the electrophoretic mobility of the $\alpha$-subunit with the use of the affinity labelling technique. Partially purified insulin receptors were incubated with ${ }^{125} \mathrm{I}$-insulin and dissuccinimidyl suberate under reducing conditions. A protein with a molecular mass of approximately $135 \mathrm{kDa}$ was labelled, corresponding to the $\alpha$-subunit of the insulin receptor, and its radioactivity was totally displaced by an excess of unlabelled insulin $\left(10^{-7} \mathrm{~mol} / \mathrm{l}\right)$, supporting the specificity of insulin binding to this band. The electrophoretic migration of the cross-linked $\alpha$-subunit of the insulin receptor was similar in hypomagnesaemic and control rats. In these cross-linking experiments, we used the same amount of protein as in those for ${ }^{125}$ I-insulin binding, and tyrosine kinase activity experiments.

Glucose transporter protein GLUT 4. To study the effect of magnesium deficiency on the insulin-sensitive glucose transporter (GLUT 4), Western blot analyses were performed using a polyclonal antisera specific for the carboxyl-terminal peptide of GLUT 4. Figure 5 shows the approximately $45 \mathrm{kDa}$ band corresponding to GLUT 4 obtained by autoradiography, from the gastrocnemius muscles of two control and two hypomagnesaemic rats. The abundance of the glucose transporter protein was quantitated by densimetometry which revealed no significant differences between control $(3.55 \pm 0.65$ arbitrary units $/ 50 \mu \mathrm{g}$ of protein, $n=5)$ and hypomagnesaemic rats (3.54 \pm $0.37 \mathrm{U} / 50 \mu \mathrm{g}$ of protein, $n=5$ ).

\section{Discussion}

This study was designed in order to reach a better understanding of the mechanism involved in the production of insulin resistance by hypomagnesaemia. We used the experimental model of hypomagnesaemia induced in rats with a diet containing low- $\mathrm{Mg}^{+2}$ for 4 days. This diet produced a reduction of serum $\mathrm{Mg}^{+2}$ levels in all the rats, although the levels ranged from severe to moderate low values.

In order to evaluate the effect of hypomagnesaemia on the in vivo insulin secretion and action, we performed an i.v. glucose load. Hypomagnesaemic rats had high basal glycaemic levels and a low glu- 

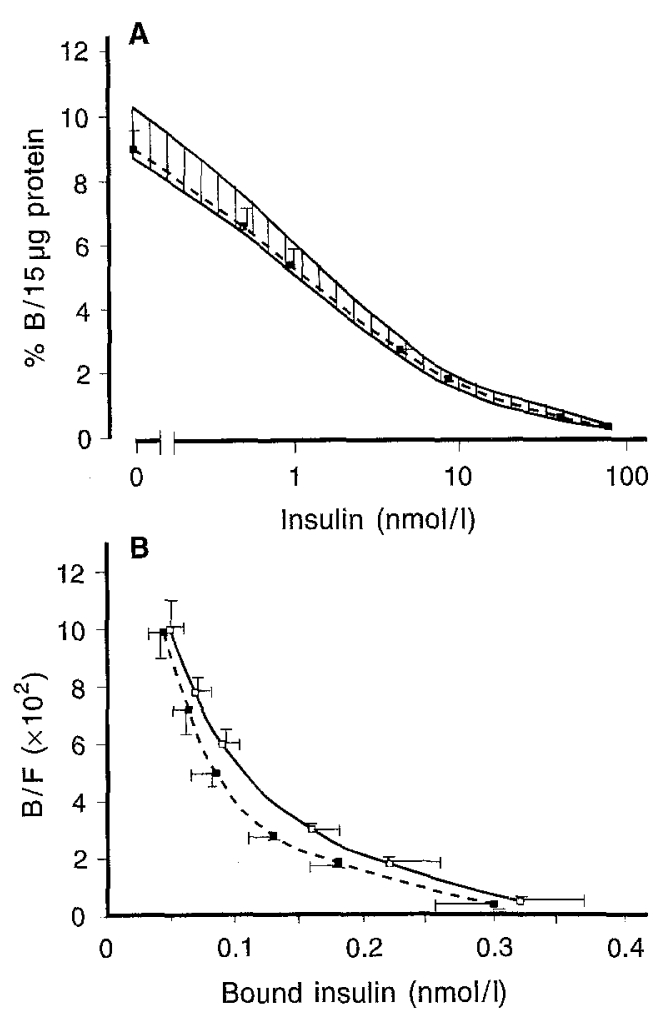

Fig.3. A. Specific ${ }^{125} \mathrm{I}$-insulin binding to WGA-purified muscle insulin receptors from hypomagnesaemic rats ( $\square-\cdots, n=13$, mean $\pm \mathrm{SEM}$ ). Shaded area represents the mean $\pm 1 \mathrm{SEM}$ $(n=9)$ of the specific insulin binding to receptors from the control group. B. Scatchard plots of the binding data from hypomagnesaemic (----) and control rats ( $\square-\square)$

cose disappearance rate; these alterations were associated with normal basal serum insulin levels and a low glucose-stimulated insulin secretion. These data indicate that hypomagnesaemia affects glucose metabolism at different levels; decreasing the ability of pancreatic beta cells to secrete insulin in response to glucose and producing a state of basal insulin resistance. A normal basal insulinaemia and a low glucose-stimulated insulin secretion, after an i.v. or i.p. glucose load, have also been reported in hypomagnesaemic rats [29-31]. It has been shown that the pancreases from these rats have a low insulin content [29]. The mechanism responsible for the lowering effect of hypomagnesaemia on insulin secretion remains unclear. The possibility of a direct effect of hypomagnesaemia on insulin secretion has been considered, but not demonstrated. In fact, there are contradictory results on the evaluation of the omission of magnesium ion in the medium of pancreas perfusates or in the incubation medium of islets. In these studies either a low insulin synthesis and secretion, an unchanged insulin secretion, or a high insulin secretion have been reported [32-39]. However, there is a consensus on the inhibitory effect of hypermagnesaemia on insulin secretion. The above, apparently contradictory results have been focused to-
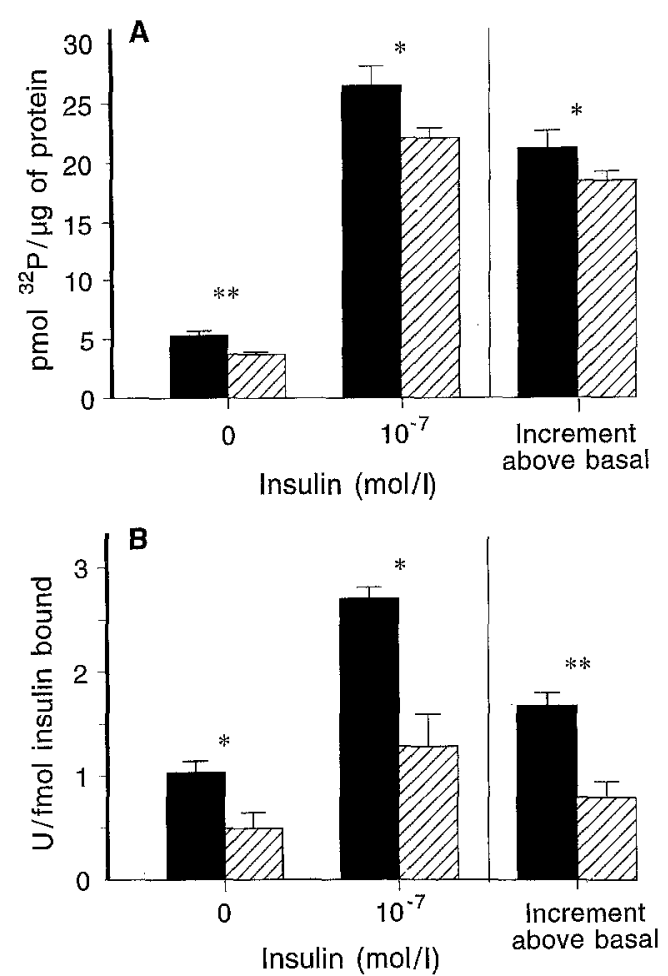

Fig. 4. A. Phosphorylation of exogenous substrate Poly Glu4:Tyr1 by WGA-purified muscle insulin receptors from control $(\square, n=7)$ and hypomagnesaemic rats $(\because, n=13)$, in the absence and presence of $10^{-7} \mathrm{~mol} / \mathrm{l}$ insulin; data expressed as the amount of pmol of ${ }^{32} \mathrm{P}$ incorporated into exogenous substrate per $\mu \mathrm{g}$ of receptor protein. ${ }^{*} p<0.05 ; * * p<0.01$ vs control. B. Autophosphorylation of $\beta$-subunit of muscle insulin receptors from control $(n=5)$ and hypomagnesaemic rats $(n=5)$, in the absence and presence of $10^{-7} \mathrm{~mol} / \mathrm{l}$ insulin. Results expressed as arbitrary units per amount of insulin receptor preparation that binds 1 fmol of insulin. * $p<0.05$; $* * p<0.01$ vs control group (mean \pm SEM)

wards a theory that an optimal ratio between $\mathrm{Ca}^{+2} /$ $\mathrm{Mg}^{+2}$ in the pancreas is necessary for an adequate insulin secretion. The hypomagnesaemia in rats is usually associated with hypercalcaemia. In our study, hypomagnesaemic rats had only a moderate increase in serum calcium levels. However, it is possible that an imbalance between the two cations could contribute to the altered glucose-stimulated insulin secretion observed in the hypomagnesaemic rats. Another mechanism that has been postulated for the low insulin secretion present in hypomagnesaemic rats is a probable low pancreatic $\mathrm{K}^{+}$content [40]. Although we did not measure the $\mathrm{K}^{+}$content in pancreas or in skeletal muscle, there is evidence of a low $\mathrm{K}^{+}$content in various tissues of hypomagnesaemic rats; i. e. skeletal muscle, liver and heart, in association with either normal or low serum $\mathrm{K}^{+}$levels [41-43]. Therefore, the independent role of $\mathrm{Mg}^{+2}$ and $\mathrm{K}^{+}$on the impaired glucose-induced insulin secretion in hypomagnesaemia remains to be clarified.

In order to ascertain if insulin resistance, which was evident in the basal situation, could contribute 


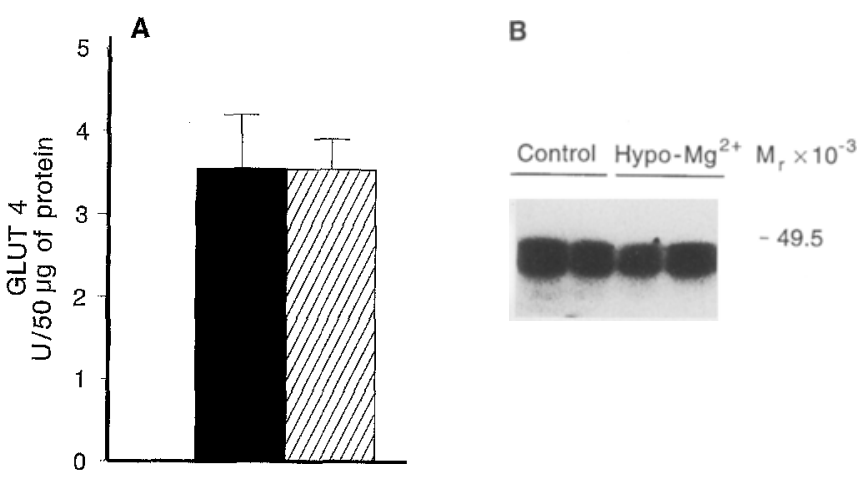

Fig.5. A. Quantitation of glucose transporter protein GLUT 4 in skeletal muscle from control $(\square, n=5)$ and hypo-

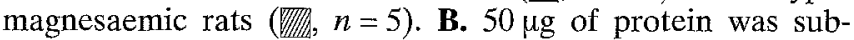
jected to SDS-PAGE in $10 \%$ acrylamide resolving gel under reducing conditions. Proteins were transferred to Immobilon membrane and immunoblotted with polyclonal antiserum raised in rabbits against the carboxyl-terminal peptide of GLUT 4, as described in Methods. The $45 \mathrm{kDa}$ band from autoradiogram was scanned and results are expressed as arbitrary units $/ 50 \mu \mathrm{g}$ of protein (mean $\pm \mathrm{SEM}$ )

to the decreased glucose disappearance rate after the i.v. glucose load observed in the group of hypomagnesaemic rats, we performed "ex vivo" and "in vitro" studies in skeletal muscle, the major peripheral target tissue of insulin.

In the hindquarter perfusion experiments, magnesium-deficient rats presented a tendency to have a high basal glucose uptake and a low insulin-stimulated glucose utilization, with a $50 \%$ reduction in insulin sensitivity. In spite of a trend towards a higher basal glucose disposal by the hindquarter preparations, hypomagnesaemic rats presented basal hyperglycaemia. This could be due to a high hepatic glucose production related to a more widespread insulin resistance, which also affects the liver. In addition, an increase in the hepatic gluconeogenic enzyme phosphoenolpyruvate carboxykinase has been reported in hypomagnesaemic rats [31]. Our results on basal glucose uptake agree with those of Kahil et al. [44], showing a high penetration and phosphorylation of 2-deoxyglucose in the intact diaphragm from hypomagnesaemic rats. The effect of hypomagnesaemia on the insulin-stimulated glucose uptake by skeletal muscle has also been previously investigated. In elderly non-insulin-dependent diabetic subjects with a moderate decrease of serum $\mathrm{Mg}^{+2}$ levels, administration of $\mathrm{Mg}^{+2}$ supplements for a month was shown to significantly increase the glucose disposal stimulated by insulin during a euglycaemic hyperinsulinaemic clamp [10]. It has been reported that hypomagnesaemia induced in rats by feeding a high-fructose-containing diet produced a decrease in the submaximal insulin-stimulated glucose uptake by the perfused hindquarters, which could be prevented by supplementing the high-fructose diet with magnesium [45]. The acute effect of hypomagnesaemia was investi- gated in soleus muscles from normal rats, depleted of endogenous $\mathrm{Mg}^{+2}$ by pretreatment with EDTAcontaining medium; insulin at the concentration assayed of $0.1 \mathrm{IU} / \mathrm{ml}$ was unable to stimulate glucose uptake, but the addition of a low $\mathrm{Mg}^{+2}$ concentration $(0.1 \mathrm{mmol} / \mathrm{l})$ to the incubation medium was enough to restore the insulin response [46]. In our study we used a perfusion medium containing a physiological concentration of $\mathrm{Mg}^{+2}(1.2 \mathrm{mmol} / \mathrm{l})$, thus, under these conditions, the circulating $\mathrm{Mg}^{+2}$ levels were restored. However, the insulin sensitivity for glucose uptake was clearly reduced in the group of magnesium-deficient rats. In these rats we found a moderate decrease in the skeletal muscle content of $\mathrm{Mg}^{+2}$ in comparison with that in the control group. Therefore, magnesium deficiency may cause disturbances in the mechanisms implicated in the insulin-stimulated glucose transport/metabolism, although not high enough to reduce the response to maximal insulin concentrations as was the case in our study and also in the previously-mentioned studies performed in rats fed with a high fructose diet [45] and in normal muscles depleted of $\mathrm{Mg}^{+2}$ [46].

The first step in insulin action is its binding to specific receptors located at the plasma membrane. Therefore, we studied the insulin binding kinetics to partially-purified solubilized receptors from total homogenates of gastrocnemius muscles. The group of hypomagnesaemic rats had no changes in the displacement curve of ${ }^{125}$ I-insulin binding to muscle receptors; and both binding affinity and insulin binding capacity were similar to those in the control group. These results agree with those documented by Gould and Chaudry [46] of normal insulin binding to soleus muscles depleted of $\mathrm{Mg}^{+2}$ by pretreatment with EDTA. We have previously reported normal insulin binding to erythrocytes in patients with severe hypomagnesaemia [11].

In order to ascertain if the structure of the $\alpha$-subunit of the insulin receptor would be influenced by magnesium deficiency, we performed insulin-receptor cross-linking experiments under reducing conditions. In this study a normal displacement of ${ }^{125} \mathrm{I}$-insulin by unlabelled insulin to its binding to the $\alpha$-subunit of receptor was found again. The $\alpha$-subunit of the muscle insulin receptor from hypomagnesaemic rats had a similar electrophoretic mobility to that in the control rats, with a molecular mass of $\sim 135 \mathrm{kDa}$.

Once insulin is bound to its receptor, an immediate activation of the tyrosine kinase present in the $\beta$-subunit of the insulin receptor takes place. This reaction is considered to be the first signalling mechanism of insulin action. The activation of the receptor tyrosine kinase produces the phosphorylation in tyrosine residues of its own $\beta$-subunit of the receptor (autophosphorylation) as well as the tyrosine phosphorylation of intracellular substrates or exogenous substrates. Therefore, we decided to determine if 
magnesium deficiency would alter the enzymatic activity of the muscle insulin receptors. The group of hypomagnesaemic rats presented a significant reduction in both basal and insulin-stimulated insulin receptor tyrosine kinase activity, determined as the ability to phosphorylate its own $\beta$-subunit as well as the exogenous substrate Poly Glu4:Tyr1. The insulin receptor kinase activity from $\mathrm{Mg}^{+2}$-deficient rats was more defective in inducing the autophosphorylation of the $\beta$-subunit; the increment above the basal value of the autophosphorylation induced by insulin represented $50 \%$ of the control, whereas the increment of the phosphorylation of Poly Glu4:Tyr1 represented $80 \%$ of the control. It is important to understand that these results were obtained from in vitro studies and that these experiments were performed in the presence of optimal concentrations of $\mathrm{Mg}^{+2}$. Therefore, it is possible that the receptor kinase disturbance will become worse in the intact situation of hypomagnesaemia. The defective autophosphorylation of the $\beta$-subunit of muscle insulin receptors from hypomagnesaemic rats could not be attributed to major changes in the structure of the $\beta$-subunit, as the electrophoretic mobility of the subunit was identical to that in the control group, with an apparent molecular mass of $95 \mathrm{kDa}$.

Glucose transport is mediated by a family of glucose transporter isoforms with distinct structure, function and tissue distribution [47-49]. Skeletal muscle expresses the isoforms GLUT 1 and GLUT 4. GLUT 1 mediates the glucose uptake in the basal situation, whereas GLUT 4, which is specific for adipose and skeletal muscle tissues, is responsible for insulin-stimulated glucose transport. In order to see if hypomagnesaemia would influence the expression of the GLUT 4 protein, we measured it in solubilized homogenates of gastrocnemius muscles. No differences in the total GLUT 4 content of skeletal muscle were found between magnesium-deficient rats and control rats. However, further studies are required in order to know if hypomagnesaemia alters the activation/translocation of the GLUT 4, as those mechanisms need to be intact for an adequate insulin-stimulated glucose transport.

The relationship between magnesium and diabetes mellitus has attracted greater interest in recent years. The results of our work clearly demonstrate that magnesium deficiency produces a deleterious effect on glucose handling which seems to be due to both a decrease in insulin secretion and sensitivity. A deficient magnesium intake is a risk factor for the development of non-insulin-dependent diabetes in women [50]. Furthermore, there is evidence of a preventive role of dietary magnesium supplementation in the development of spontaneous type 2 diabetes in rats [51].

Although the mechanism by which the insulin secretion was impaired in hypomagnesaemic rats needs further clarification, the low insulin sensitivity observed in these rats may be attributed, at least in part, to a defective tyrosine kinase activity of muscle insulin receptors.

Acknowledgements. We are grateful to Dr. J.P. Albar, from the Centro Nacional de Biotecnología-Pharmacia, Madrid, Spain, for the synthesis of the carboxyl-terminal peptide of GLUT 4, and to Dr. M. Luisa Traba from the Unidad Metabólica, Fundación Jiménez Díaz, for the measurements of magnesium. We want to thank Ms. A. Manzano for her technical assistance. This work was supported by a grant from the Instituto Nacional de la Salud (FIS 93/0302).

\section{References}

1. Lostroh AJ, Krahl ME (1973) Accumulation in vitro of $\mathrm{Mg}^{2+}$ and $\mathrm{K}^{+}$in rat uterus: ion pump activity. Bioch Biophys Acta 291: 260-268

2. Paolisso G, Sgambato S, Passariello N et al. (1986) Insulin induces opposite changes in plasma and erythrocyte magnesium concentrations in normal man. Diabetologia 29 : 644-647

3. Paolisso G, Sgambato S, Giugliano D et al. (1988) Impaired insulin-induced erythrocyte magnesium accumulation is correlated to impaired insulin-mediated glucose disposal in type 2 (non-insulin-dependent) diabetic patients. Diabetologia 31: 910-915

4. Paolisso G, Pizza G, Riu S et al. (1990) Impaired insulinmediated erythrocyte magnesium accumulation is correlated to impaired insulin-mediated glucose diposal in aged non-diabetic obese patients. Diabetes Metab 16: 328-333

5. Paolisso G, Passariello N, Sgambato S et al. (1987) Impaired insulin-mediated erythrocyte magnesium accumulation in essential hypertension. Clin Sci 73: 535-539

6. Lehninger AS (1950) Role of metal ions in enzyme systems. Physiol Rev 30: 393-429

7. Lostroh AJ, Krahl ME (1974) Magnesium a second messenger for insulin: ion translocation coupled to transport activity. Adv Enzyme Regul 12: 73-81

8. Moles KW, McMullen JK (1982) Insulin resistance and hypomagnesaemia: case report. BMJ 285: 262

9. Yajnik CS, Smith RF, Hockaday TDR, Ward NI (1984) Fasting plasma magnesium concentrations and glucose disposal in diabetes. BMJ 288: 1032-1034

10. Paolisso G, Sgambato S, Pizza G, Passariello N, Varricchio M, D'Onofrio F (1989) Improved insulin response and action by chronic magnesium administration in aged NIDDM subjects. Diabetes Care 12: 265-269

11. Rapado A, Rovira A, Grant C, Casla A (1990) Insulin resistance in patients with hypomagnesemia. Magnesium Res 3: 56 (Abstract)

12. Kadowaki T, Kasuga M, Akanuma Y, Ezaki O, Takaku F (1984) Decreased autophosphorylation of the insulin receptor-kinase in streptozotocin-diabetic rats. J Biol Chem 259: $14208-14216$

13. Okamoto M, White MF, Maron R, Kahn R (1986) Autophosphorylation and kinase activity of insulin receptor in diabetic rats. Am J Physiol 251: E542-E550

14. Le Marchand-Brustel Y, Grémeaux T, Ballotti R, van Obberghen $\mathrm{E}$ (1985) Insulin receptor tyrosine kinase is defective in skeletal muscle of insulin-resistant obese mice. Nature 315: 676-679

15. Caro FJ, Ittoop O, Pories WJ et al. (1986) Studies on the mechanism of insulin resistance in the liver from humans with noninsulin-dependent diabetes. J Clin Invest 78: 249258 
16. Simon J, Rosebrough RW, McMurtry JP et al. (1986) Fasting and refeeding alter the insulin receptor tyrosine kinase in chicken liver but fail to affect brain insulin receptors. $J$ Biol Chem 261: 17081-17088

17. Greenwood FC, Hunter WM, Glover JS (1963) The preparation of ${ }^{131}$ I-labelled human growth hormone of high specific radioactivity. Biochem J 89: 114-123

18. Herbert V, Lau KS, Gottlieb CW, Bleicher SJ (1965) Coated charcoal immunoassay of insulin. J Clin Endocrinol Metab 25: 1375-1384

19. Varnum B, Davidson MB, Venkatesan N (1985) Insulin secretion and action in the hyperthyroid rat. Horm Metab Res 17: 383-386

20. Ruderman NB, Houghton CRS, Hems R (1971) Evaluation of the isolated perfused rat hindquarter for the study of muscle metabolism. Biochem J 124: 639-651

21. Dohm GL, Kasperek GJ, Tapscott EB, Beecher GR (1980) Effect of exercise on synthesis and degradation of muscle protein. Biochem J 188: 255-262

22. Hedo JA, Harrison LC, Roth J (1981) Binding of insulin receptors to lectins: evidence for common carbohydrate determinants on several membrane receptors. Biochemistry 20: 3385-3393

23. Bradford MM (1976) A rapid and sensitive method for the quantitation of microgram quantities of protein utilizing the principle of protein-dye binding. Anal Biochem 72: 248-254

24. Scatchard G (1949) The attractions of proteins for small molecules and ions. Ann NY Acad Sci 51: 660-672

25. Grunberger G, Zick Y, Roth J, Gorden P (1983) Protein kinase activity of the insulin receptor in human circulating and cultured mononuclear cells. Biochem Biophys Res Commun 115: 560-566

26. Laemmli UK (1970) Cleavage of structural proteins during the assembly of the head of bacteriophage T4. Nature 227: 680-685

27. Pilch PF, Czech MP (1980) The subunit structure of the high affinity insulin receptor: evidence for a disulfide linked receptor complex in fat cell and liver plasma membranes. J Biol Chem 255: 1722-1731

28. James DE, Strube M, Mueckler M (1989) Molecular cloning and characterization of an insulin-regulatable glucose transporter. Nature 338: 83-87

29. Legrand C, Okitolonda W, Pottier AM, Lederer J, Henquin JC (1987) Glucose homeostasis in magnesium-deficient rats. Metabolism 36: 160-164

30. Gueux E, Rayssiguier Y (1983) The effect of magnesium deficiency on glucose stimulated insulin secretion in rats. Horm Metab Res 15: 594-597

31. McNeill DA, Herbein JH, Ritchey SJ (1982) Hepatic gluconeogenic enzymes, plasma insulin and glucagon response to magnesium deficiency and fasting. J Nutr 112: 736-743

32. Curry DL, Joy RM, Holley DC, Bennett LL (1977) Magnesium modulation of glucose-induced insulin secretion by the perfused rat pancreas. Endocrinology 101: 203-208

33. Lin BJ, Haist RE (1973) Effects of some modifiers of insulin secretion on insulin biosynthesis. Endocrinology 92 : $735-742$
34. Milner RDG, Hales CN (1967) The role of calcium and magnesium in insulin secretion from rabbit pancreas studied in vitro. Diabetologia 3: 47-49

35. Malaisse WJ, Brisson G, Malaisse-Lagae F (1970) The stimulus-secretion coupling of glucose-induced insulin release. I. Interaction of epinephrine and alkaline earth cations. $J$ Lab Clin Med 76: 895-902

36. Grodsky GM, Bennett LL (1966) Cation requirements for insulin secretion in the isolated perfused pancreas. Diabetes 15: 910-913

37. Lambert AE, Jeanrenaud B, Junod A, Renold AE (1969) Organ culture of fetal rat pancreas. II. Insulin release induced by amino and organic acids, by hormonal peptides, by cationic alterations of the medium and by other agents. Biochim Biophys Acta 184: 540-553

38. Leclercq-Meyer V, Marchand J, Malaisse WJ (1973) The effect of calcium and magnesium on glucagon secretion. Endocrinology 93: 1360-1370

39. Bennett LL, Curry DL, Grodsky GM (1969) Calcium-magnesium antagonism in insulin secretion by the perfused rat pancreas. Endocrinology 85: 594-596

40. Henquin JC, Lambert AE (1974) Cationic environment and dynamics of insulin secretion III. Effect of the absence of potassium. Diabetologia 10: 789-794

41. Whang R, Welt LG (1963) Observations in experimental magnesium depletion. J Clin Invest 42: 305-313

42. MacIntyre I, Davidsson D (1958) The production of secondary potassium depletion, sodium retention, nephrocalcinosis and hypercalcaemia by magnesium deficiency. Biochem J 70: 456-462

43. George GA, Heaton FW (1975) Changes in cellular composition during magnesium deficiency. Biochem $\mathrm{J} 152$ : 609-615

44. Kahil ME, Simons EL, Brown H (1968) Magnesium deficiency and sugar transport in muscle. Diabetes 17: 673-678

45. Balon TW, Jasman A, Scott S, Meehan WP, Rude RK, Nadler JL (1994) Dietary magnesium prevents fructose-induced insulin insensitivity in rats. Hypertension 23 (part 2): $1036-1039$

46. Gould MK, Chaudry IH (1970) The action of insulin on glucose uptake by isolated rat soleus muscle. I. Effects of cations. Biochim Biophys Acta 215: 249-257

47. Fukumoto H, Seino S, Imura H et al. (1988) Sequence, tissue distribution, and chromosomal localization of mRNA encoding a human glucose transporter-like protein. Proc Natl Acad Sci USA 85: 5434-5438

48. James DE, Brown R, Navarro J, Pilch PF (1988) Insulinregulatable tissues express a unique insulin-sensitive glucose transport protein. Nature 333: 183-185

49. Kayano T, Fukumoto H, Eddy RL et al. (1988) Evidence for a family of human glucose transporter-like proteins. $J$ Biol Chem 263: 15245-15248

50. Colditz GA, Manson JE, Stampfer MJ, Rosner B, Willett WC, Speizer FE (1992) Diet and risk of clinical diabetes in women. Am J Clin Nutr 55: 1018-1023

51. Balon T, Jasman A, Scott S, Gu JL, Nadler J (1994) Evidence that dietary magnesium supplementation prevents the development of diabetes in a rat model of spontaneous NIDDM. Diabetes 43 [Suppl 1]: 88 (Abstract) 